\title{
PENGARUH MODEL PEMBELAJARAN AUDITORY INTELLECTUALLY REPETITION (AIR) TERHADAP HASIL BELAJAR SISWA PADA MATA PELAJARAN EKONOMI KELAS X IPS DI SMA NEGERI 3 SINGARAJA TAHUN PELAJARAN 2017/2018
}

\author{
Ni Kadek Martini ${ }^{1}$, Lulup Endah Tripalupi ${ }^{2}$, Iyus Akhmad Haris ${ }^{3}$ \\ Jurusan Pendidikan Ekonomi \\ Universitas Pendidikan Ganesha \\ Singaraja, Indonesia

\begin{abstract}
email: kadekmartini001@gmail.com¹, lulup tripalupi@yahoo.com²,
\end{abstract} \\ iyus.haris@gmail.com ${ }^{3}$
}

\begin{abstract}
Abstrak
Penelitian ini merupakan penelitian eksperimen semu dengan rancangan "Post Test Only, NonEquivalent Control Grup Design" yang bertujuan untuk mengetahui apakah terdapat perbedaan hasil belajar siswa pada mata pelajaran ekonomi antara kelompok siswa yang belajar dengan menggunakan model pembelajaran Auditory Intellectually Repetition (AIR) dengan kelompok siswa yang belajar tidak dengan menggunakan model pembelajaran Auditory Intellectually Repetition (AIR)pada siswa kelas X IPS di SMA Negeri 3 Singaraja. Data mengenai hasil belajar ekonomi dikumpulkan dengan menggunakan tes hasil belajar yang diberikan pada akhir penelitian. Data hasil belajar ekonomi siswa selanjutnya dianalisis dengan uji-t pada taraf signifikansi $5 \%$. Dari hasil penelitian menunjukkan bahwa terdapat perbedaan hasil belajar siswa pada mata pelajaran ekonomi antara kelompok siswa yang belajar dengan menggunakan model pembelajaran Auditory Intellectually Repetition (AIR) dengan kelompok siswa yang belajar tidak dengan menggunakan model pembelajaran Auditory Intellectually Repetition (AIR)yang ditunjukkan dari nilai sig $<0,05(0,000<0,05)$.
\end{abstract}

Kata kunci : model pembelajaran, Auditory Intellectually and Repetition (AIR), hasil belajar

\begin{abstract}
This research was a quasi experimen research with the design of "Post Test Only, Non-Equivalent Control Group Design" which aimed to find out whether there were differences in student learning outcomes on economic subjects between groups of students who learned by using the learning model of Auditory Intellectually Repetition (AIR) with group of students who did not learn by using the learning model of Auditory Intellectually Repetition (AIR) in class of X IPS students in SMA Negeri 3 Singaraja. Data on economic learning outcomes were collected using the learning result test provided at the end of the study. The data of students' economic learning result was then analyzed by t-test at $5 \%$ significance level. The result of the research showes that there were differences of students' learning outcomes in economic subjects between groups of students who learned by using the learning model of Auditory Intellectually Repetition (AIR) with the group of who learned not by using the Auditory Intellectually Repetition (AIR) learning model which was shown from the $<0,05(0,000<0,05)$.
\end{abstract}

Keyboard : learning model, Auditory Intellectually and Repetition (AIR), learning outcomes.

\section{PENDAHULUAN}

Pesatnya

perkembangan IImu

Pengetahuan dan Teknologi (IPTEK) serta persaingan di era globalisasi yang semakin ketat menuntut adanya kualitas Sumber Daya Manusia (SDM) yang handal. Kualitas SDM yang handal tersebut adalah SDM yang mempunyai daya saing secara terbuka dan global terhadap berbagai perubahan dan kondisi yang dinamis, terbuka terhadap perubahan, serta memiliki dasar-dasar kemampuan luas, kuat, dan mendasar untuk berkembang di masa yang akan datang (Wagiran dalam Handayani, 
2013). Untuk dapat mencetak SDM yang handal dan mampu bersaing secara global dibutuhkan proses pendidikan yang menjadikan siswa mandiri dan terampil serta berkualitas. Indonesia sebagai negara yang berkembang, terus berupaya untuk meningkatkan kualitas SDM. Hal ini tertuang dalam tujuan pendidikan nasional Indonesia, yaitu meningkatkan kualitas manusia yang beriman dan bertakwa kepada Tuhan Yang Maha Esa, berbudi pekerti luhur, berkepribadian mandiri, maju, tangguh, cerdas, kreatif, produktif, serta sehat jasmani dan rohani.

Selain itu, dalam UU No 20 tahun 2013 pasal 1 ayat 1 tentang sistem pendidikan nasional disebutkan bahwa pendidikan adalah usaha sadar dan terencana untuk mewujudkan suasana belajar dan proses pembelajaran agar siswa secara aktif mengembangkan potensi dirinya untuk memiliki kekuatan spiritual keagamaan, pengendalian diri, kepribadian, kecerdasan, akhlak mulia, serta keterampilan yang diperlukan dirinya, masyarakat, bangsa dan negara. Implikasi dari pendidikan yang dimaksud dalam pasal 1 ayat 1 tentang Sisdiknas berawal dari pergeseran paradigma proses pembelajaran yaitu pembelajaran yang berpusat pada guru menjadi pembelajaran yang berpusat kepada siswa (Sukmadinata, 2009).

Sekolah merupakan tempat berlangsungnya kegiatan belajar mengajar untuk memperoleh output SDM yang handal, karena di sekolah terjadi interaksi secara langsung antara siswa sebagai siswa dan guru sebagai pendidik dalam suatu proses pembelajaran. Sekolah juga dijadikan dasar untuk melaksanakan tujuan yang ingin dicapai oleh pembangunan pendidikan. Dengan melakukan kegiatan pembelajaran sesuai kebutuhan yang diperlukan oleh masyarakat. Melalui berbagai kegiatan pembelajaran disetiap bidang studi, diharapkan dapat mencapai tujuan dari pembangunan pendidikan, salah satunya adalah pembelajaran ekonomi.

Ekonomi adalah studi tentang bagaimana masyarakat mengelola sumbersumber daya yang selalu terbatas atau langka. Serta ekonomi merupakan salah satu ilmu yang berguna bagi kehidupan sehari-hari yang dituntut sesuai perkembangan zaman. Tujuan dari pembelajaran ekonomi di sekolah adalah agar peserta didik memiliki kemampuan memahami sejumlah konsep ekonomi untuk mengkaitkan peristiwa dan masalah ekonomi dengan kehidupan sehari-hari, terutama yang terjadi di lingkungan individu, rumah tangga, masyarakat, dan Negara, menampilkan sikap ingin tahu terhadap sejumlah konsep ekonomi yang diperlukan untuk mendalami ilmu ekonomi, membentuk sikap bijak, rasional dan bertanggung jawab dengan memiliki pengetahuan dan keterampilan ilmu ekonomi, manajemen dan akuntansi yang bermanfaat bagi diri sendiri, rumah tangga, masyarakat dan negara, dan membuat keputusan yang bertanggung jawab mengenai nilai-nilai sosial ekonomi dalam masyarakat yang majemuk, baik dalam skala nasional maupun internasional (Neti \& Leni, 2010).

Keberhasilan siswa dalam mencapai tujuan belajar dapat dilihat dari hasil belajar siswa. Hasil belajar memiliki peranan penting dalam proses pembelajaran. Menurut Slameto (2010:2) "hasil belajar merupakan suatu proses usaha yang dilakukan seseorang untuk memperoleh suatu perubahan tingkah laku yang baru secara keseluruhan, sebagai hasil pengalamannya sendiri dalam interaksi lingkungan". Selain itu menurut Reigeluth (dalam Uno, 2012) menyebutkan bahwa hasil belajar adalah semua efek yang dapat dijadikan sebagai indikator tentang nilai dari penggunaan suatu metode di bawah kondisi yang berbeda. Hasil belajar merupakan gambaran konkrit keberhasilan proses belajar mengajar yang berlangsung di institusi pendidikan. Nilai yang diperoleh siswa menjadi acuan untuk melihat penguasaan siswa dalam menerima materi pelajaran. Hasil belajar dapat dilihat melalui kegiatan evaluasi yang bertujuan untuk mendapatkan data pembuktian yang akan menunjukkan tingkat kemampuan siswa dalam mencapai tujuan pembelajaran. Berikutnya menurut Purwanto (2011:54), "hasil belajar adalah perubahan tingkah laku yang terjadi setelah mengikuti proses belajar mengajar sesuai dengan tujuan 
pendidikan". Berdasarkan pengertian hasil belajar di atas dapat disimpulkan bahwa hasil belajar adalah kemampuankemampuan yang dimiliki siswa setelah menerima pengalaman belajarnya yang dicapai dalam bentuk angka-angka atau skor setelah diberikan tes hasil belajar pada setiap akhir pembelajaran

Hasil belajar menurut B.S Bloom (dalam Sudijono, 2009) dibagi menjadi tiga ranah yaitu ranah kognitif, ranah afektif, dan ranah psikomotor. Ranah kognitif adalah ranah yang mencakup kegiatan mental atau otak, Ranah afektif adalah ranah yang berkaitan dengan sikap dan nilai. Dan ranah psikomotor adalah ranah yang berkaitan dengan keterampilan (skill) atau kemampuan bertindak setelah seseorang menerima pengalaman belajar tertentu.

Hasil belajar salah satunya ditinjau dari ranah kognitif. Dalam ranah kognitif itu terdapat 6 (enam) jenjang proses berpikir, mulai dari jenjang terendah sampai dengan jenjang yang paling tinggi. Dalam ranah kognitif hasil belajar juga merupakan tolak ukur tingkat pemahaman siswa terhadap materi tertentu yang telah diberikan, setelah siswa mengalami proses belajar pada waktu tertentu dan dinyatakan dalam bentuk nilai. Namun, dalam kegiatan belajar mengajar di sekolah, sering dijumpai berbagai permasalahan. Salah satunya yaitu rendahnya hasil belajar siswa dalam pelajaran ekonomi.

Kondisi ini atau rendahnya hasil belajar ini ditemukan di SMA Negeri 3 Singaraja, banyak siswa yang masih memiliki nilai rendah pada mata pelajaran ekonomi. Hasil belajar ekonomi yang dicapai siswa masih banyak yang berada di bawah standar yang ditetapkan. Salah satunya dapat dilihat dari hasil Ulangan Harian pada bab satu. Dari jumlah siswa dikelas X IPS sebanyak 100 siswa, yang memenuhi KKM (Kriteria Ketuntasan Minimum) hanya 25 siswa dan sisanya sebanyak 75 siswa masih dibawah KKM. Dengan nilai rata-rata kelas $X$ IPS 1 yaitu 64,71 , nilai rata-rata kelas X IPS 2 yaitu 64,24 , dan nilai rata-rata kelas X IPS 3 yaitu 61,36 .

Hasil belajar yang rendah dapat disebabkan oleh beberapa faktor yang mempengaruhi proses belajar. Menurut Sumadi Suryabrata (2006) hasil belajar dipengaruhi oleh faktor internal dan eksternal. Faktor internal adalah faktor yang bersumber dari dalam diri individu yang menyangkut seluruh pribadi dan karakteristik siswa. Karakteristik ini seperti bakat, kebutuhan, minat, gaya belajar, dan kecenderungan atau pilihan perorangan. Sedangkan faktor eksternal adalah faktor yang bersumber dari luar diri individu yang dapat mempengaruhi hasil belajar. Adapun faktor eksternal yang mempengaruhi hasil belajar siswa yaitu lingkungan sosial dan lingkungan non sosial.

Menurut Slameto (2010) ada beberapa faktor yang mempengaruhi belajar, yaitu faktor internal yang terdiri dari faktor jasmaniah, psikologis dan kelelahan serta faktor eksternal yang terdiri dari faktor keluarga, sekolah dan masyarakat. Faktor eksternal misalnya pemilihan model pembelajaran yang tidak tepat, kurangnya media yang digunakan, serta metode pembelajaran yang digunakan guru kurang bervariasi. Pada proses belajar mengajar selama ini masih menggunakan sistem belajar yang berpusat pada guru (teacher centered) karena pada umumnya para guru masih menggunakan metode ceramah. Dengan metode tersebut membuat siswa cenderung pasif atau tidak aktif dalam pelaksanaan pembelajaran ekonomi. Siswa lebih banyak mendengarkan guru berbicara tanpa berusaha membangun pengetahuan siswa secara mandiri. Siswa perlu dilibatkan secara aktif dalam proses pembelajaran agar siswa dapat membangun atau mendapatkan pengetahuan secara mandiri. Salah satunya dengan menerapkan suatu pembelajaran yang melibatkan siswa secara aktif. Menurut Santayasa (dalam Trianto, 2007:48), "model pembelajaran merupakan kerangka konseptual yang melukiskan prosedur yang sistematis dalam mengorganisasikan pengalaman belajar untuk mencapai tujuan belajar". Selain itu, model pembelajaran pada dasarnya merupakan bentuk pembelajaran yang tergambar dari awal sampai akhir yang disajikan secara khas oleh guru. Dengan kata lain, model pembelajaran merupakan bungkus atau bingkai dari 
penerapan suatu pendekatan, metode, dan teknik pembelajaran (Komalasari, 2011).

Guru harus menciptakan kegiatan pembelajaran yang dapat mengubah konsepsi awal siswa yang belum sesuai dengan konsep materi yang akan diajarkan atau menyempurnakan konsep awal yang telah dimiliki siswa. Oleh karena itu diperlukan suatu model pembelajaran yang dapat mengubah dan menyempurnakan pengetahuan awal yang telah dimiliki siswa sesuai dengan konsep

Salah satu model pembelajaran yang melibatkan siswa secara aktif dalam pembelajaran adalah model pembelajaran Auditory Intellectually Repetition (AIR). Model pembelajaran Auditory Intellectually Repetition (AIR) merupakan salah satu alternatif model pembelajaran yang bisa diterapkan dalam pembelajaran ekonomi. Model pembelajaran AIR merupakan model pembelajaran yang menekankan tiga aspek, yaitu auditory, intellectually, dan repetition. Menurut Suherman (dalam Shoimin, 2014:29) "auditory bermakna bahwa belajar harus melalui mendengarkan, menyimak, berbicara, presentasi, argumentasi, mengemukakan pendapat, dan menanggapi”. $\quad$ ntellectually bermakna belajar harus menggunakan kemampuan berpikir, harus dengan konsentrasi pikiran dan berlatih menggunakannya melalui bernalar, menyelidiki, mengidentifikasi, menemukan, mencipta, mengonstruksi, memecahkan masalah dan menerapkan. Menurut Meier (dalam Shoimin, 2014:29) "intellctualy menunjukkan apa yang dilakukan pembelajaran dalam pemikiran suatu pengalaman dan menciptakan hubungan, makna, rencana, dan nilai dari pengalaman tersebut". Intellectually juga bermakna belajar harus menggunakan kemampuan berpikir, harus dengan konsentrasi pikiran dan berlatih menggunakannya melalui bernalar, menyelidiki, mengidentifikasi, menemukan, mencipta, mengonstruksi, memecahkan masalah dan menerapkan (Shoimin, 2014). Selain itu menurut Meier (dalam Huda, 2013) menyebutkan bahwa belajar intelektual adalah bagian untuk merenung, menciptakan, memecahkan masalah dan membangun makna. Aspek intelektual dalam belajar akan terlatih jika guru mengajak siswa terlibat dalam aktivitas-aktivitas intelektual, yaitu memecahkan masalah, menganalisis pengalaman,mengerjakan perencanaan strategis,melahirkan gagasan kreatif, mencari dan menyaring informasi, merumuskan pertanyaan, menciptakan model mental, menerapkan gagasan baru pada pekerjaan, menciptakan makna pribadi, dan meramalkan implikasi suatu gagasan. Repetition artinya pengulangan, dengan tujuan memperdalam dan memperluas pemahaman siswa yang perlu dilatih melalui pengerjaaan soal, pemberian tugas, dan kuis. Menurut Suherman (dalam Shoimin, 2014) pengulangan dalam kegiatan pembelajaran dimaksudkan agar pemahaman siswa lebih mendalam. Pengulangan dapat diberikan secara teratur, pada waktu-waktu tertentu atau setelah tiap unit yang diberikan, maupun ketika dianggap perlu pengulangan. Huda (2003) mengungkapkan bahwa pelajaran yang diulang akan memberikan tanggapan yang jelas dan tidak mudah dilupakan, sehingga dapat digunakan oleh siswa untuk memecahkan masalah. Menurut Slamet (dalam Huda, 2003) ulangan dapat diberikan secara teratur, pada waktu-waktu tertentu, atau setelah tiap unit diberikan, maupun secara insidental jika dianggap perlu. Pengulangan yang akan memberikan dampak positif adalah pengulangan yang tidak membosankan dan disajikan dalam metode yang menarik. Pengulangan dalam kegiatan pembelajaran dimaksudkan agar pemahaman siswa lebih mendalam,disertai pemberian soal dalam bentuk tugas latihan atau kuis. Dengan pemberian tugas, diharapkan siswa lebih terlatik dalam menggunakan pengetahuan yang didapat dalam menyelesaikan soal dan mengingat apa yang telah diterima. Sementara pemberian kuis dimaksudkan agar siswa siap menghadapi ujian atau tes yang dilaksanakan sewaktu-waktu serta melatih daya ingat.

Adapun langkah-langkah dalam model pembelajaran AIR (Auditory Intellectually and Repetition) menurut Shoimin (2014) yaitu, pertama siswa dibagi menjadi beberapa kelompok, masingmasing kelompok 4-5 orang, kedua siswa 
mendengarkan dan memperhatikan penjelasan dari guru, ketiga setiap kelompok mendiskusikan tentang materi yang mereka pelajari dan menuliskan hasil diskusi tersebut dan selanjutnya untuk dipresentasikan di depan kelas (auditory), keempat saat diskui berlangsung, siswa mendapat soal atau permasalahan yang berkaitan dengan materi, kelima masingmasing kelompok memikirkan cara menerapkan hasil diskusi serta dapat meningkatkan kemampuan mereka untuk menyelesaikan masalah (Intellectually), selanjutnya setelah selesai berdiskusi, siswa mendapat pengulangan materi dengan cara mendapatkan tugas atau kuis untuk tiap individu (repetition).

Dengan menggunakan model pembelajaran AIR, siswa akan memanfaatkan indera telinganya untuk mendengar penyampaian dari guru maupun penyampaian dari temannya. Selain itu, siswa juga akan melakukan presentasi, mengungkapkan pendapat, menguatkan, dan menanggapi, kemudian menggunakan kemampuan berpikirnya untuk memecahkan suatu permasalahan yang diberikan serta dilanjutkan dengan latihan untuk memantapkan apa yang telah dipelajarinya sehingga akan meningkatkan hasil belajar siswa.

Kelebihan model pembelajaran AIR (Auditory Intellectually and Repetition) menurut Shoimin (2014) yaitu siswa lebih berpartisipasi aktif dalam pembelajaran dan sering mengekspresikan idenya, siswa memiliki kesempatan lebih banyak dalam memanfatkan pengetahuan dan keterampilan, siswa dengan kemampuan rendah dapat merespon permasalahan dengan cara mereka sendiri, serta siswa memiliki pengalaman banyak untuk menemukan sesuatu dalam menjawab permasalahan serta siswa termotivasi untuk memberikan bukti atau penjelasan. Sedangkan yang menjadi kelemahan dari model pembelajaran AIR menurut Shoimin (2014) yaitu membuat dan menyiapkan masalah yang bermakna bagi siswa bukanlah pekerjaan mudah, namun dapat diatasi dengan persiapan yang lebih matang sehingga dapat menemukan masalah tersebut.

\section{METODE PENELITIAN}

Penelitian ini merupakan penelitian eksperimen semu (Quasi Experiment). Pada penelitian eksperimen semu, tidak dilakukan pengacakan individu, melainkan peneliti menerima keadaan individu-individu yang telah ditetapkan sekolah yaitu telah terbentuknya kelas-kelas yang beranggotakan sekelompok siswa. Dalam penelitian ini menggunakan desain Post Test Only, Non-Equivalent Control Grup Design. Penelitian ini bertujuan untuk mengetahui apakah terdapat perbedaan hasil belajar siswa pada mata pelajaran ekonomi antara kelompok siswa yang belajar dengan menggunakan model pembelajaran Auditory Intellectually Repetition (AIR) dengan kelompok siswa yang belajar tidak dengan menggunakan model pembelajaran Auditory Intellectually Repetition (AIR) pada siswa kelas X IPS di SMA Negeri 3 Singaraja.

Subjek penelitian dalam penelitian ini adalah siswa kelas X IPS di SMA Negeri 3 Singaraja yang terdiri dari tiga kelas dengan jumlah siswa sebanyak 106 orang siswa. Siswa kelas X IPS 1 sebagai kelompok eksperimen dan siswa kelas $X$ IPS 2 sebagai kelompok kontrol. Kelompok eksperimen merupakan kelompok yang diberikan perlakuan menggunakan model pembelajaran Auditory Intellectually and Repetition (AIR). Selanjutnya kelompok eksperimen diberikan tes akhir $\left(\mathrm{O}_{1}\right)$. Dan kelompok kontrol merupakan kelompok yang tidak diberikan perlakuan, serta selanjutnya diberikan tes akhir $\left(\mathrm{O}_{2}\right)$. Objek penelitian dalam penelitian ini adalah hasil belajar siswa dan model pembelajaran Auditory Intellectually Repetition (AIR).

Menurut Sugiyono (2010:61), "variabel independent (bebas) adalah variabel yang mempengaruhi atau yang menjadi sebab perubahannya atau timbulnya variabel idependent (terikat)." Variabel bebas ini juga disebut dengan variabel perlakuan. Variabel perlakuan yang dimaksud dalam penelitian ini adalah model pembelajaran Auditory Intellectually Repetition (AIR) yang diterapkan pada kelompok eksperimen. Variabel dependent atau variabel terikat adalah variabel akibat yang dipradugakan yang bervariasi mengikuti perubahan atau variasi variabel 
independent. Menurut Sugiyono (2010:61), "variabel terikat merupakan variabel yang dipengaruhi atau yang menjadi akibat, karena adanya variabel bebas." Variable terikat dalam penelitian ini adalah hasil belajar siswa.

Data yang diperoleh dari hasil penelitian ini adalah data kuantitatif. Data kuantitatif adalah data yang berbentuk angka. Data kuantitatif dalam penelitian ini adalah tes hasil belajar siswa pada mata pelajaran ekonomi. Sumber data yang digunakan adalah data primer dan data sekunder. Data primer yaitu data yang diperoleh secara langsung dari sumber pertama yaitu dari siswa kelas X IPS di SMA Negeri 3 Singaraja tahun ajaran 2017/2018. Data primer dalam penelitian ini berupa nilai hasil belajar siswa. Dan data sekunder yaitu data yang diperoleh dari tata usaha berupa nama siswa kelas X IPS.

Instrumen penelitian adalah alat atau fasilitas yang digunakan oleh peneliti dalam mengumpulkan data agar pekerjaannya lebih mudah dan hasilnya lebih cermat, lengkap dan sistematis sehingga lebih mudah diolah. Adapun instrumen dalam penelitian ini yaitu berupa tes hasil belajar siswa. Tes hasil belajar siswa digunakan untuk memperoleh data mengenai hasil belajar siswa. Tes ini akan diberikan pada akhir pertemuan pada kedua kelompok. Dalam penelitian ini bentuk tes yang digunakan adalah tes pilihan ganda. Menurut Slameto (dalam Sukardi, 2008) penilaian item tes pilihan ganda dapat dilakukan dengan cara penilaian yang tidak memperhitungkan jawaban salah. Artinya jawaban salah tidak mempengaruhi nilai pada jawaban benar. Nilai akhir dari item tes pilihan ganda sama dengan jumlah jawaban benar.

Sebelum kelompok eksperimen dan kelompok kontrol diberikan tes yang merupakan instrumen penelitian, terlebih dahulu dilakukan uji coba instrumen penelitian. Uji coba instrumen penelitian dilakukan untuk mendapat gambaran apakah instrumen tes hasil belajar ekonomi siswa layak digunakan sebagai instrumen penelitian. Dalam penelittian ini uji coba instrumen menggunakan uji validitas isi. Uji validitas isi dilakukan untuk menguji instrumen tes hasil belajar dengan cara konsultasi kepada dua pakar (judges). Uji validitas instrumen tes hasil belajar menggunakan formula Gregory (dalam Candiasa, 2010). Dilakukan uji validasi dimana pakar atau ahli memberikan penilaian terhadap instrumen penelitian perbutir dengan memberikan tanda check ( $)$ pada kolom "relevan" jika soal pada instrumen tersebut layak untuk digunakan dan memberikan tanda check $(\sqrt{ })$ pada kolom "tidak relevan" jika soal pada instrumen tersebut tidak layak untuk digunakan dan hasil penilaian para pakar ditabulasi dalam bentuk matriks, setelah itu dibuatkan tabulasi silang. Nilai validitas isi yang diperoleh mencerminkan keseluruhan butir tes yang dihasilkan. Setelah uji validitas isi dilakukan dan memenuhi syarat, maka tes hasil belajar dapat digunakan.

Mekanisme perhitungan validitas isi menurut Gregory (dalam Candiasa, 2010a) adalah sebagai berikut. Pertama, pakar/ahli memberikan penilaian terhadap instrumen perbutir dengan menggunakan skala 1 dan 2 adalah tidak relevan sedangkan skala 3 dan 4 adalah relevan. Kedua, mentabulasi hasil penilaian pakar ke dalam bentuk matriks tabulasi silang $(2 \times 2)$. Ketiga, memasukan data hasil tabulasi silang ke dalam rumus validitas isi. Setelah dilakukan uji validitas isi, instrument penelitian diujicobakan.

Setelah kelompok eksperimen dan kelompok kontrol diberi perlakuan dan diberikan post-tes hasil belajar siswa kemudian dilakukan uji hipotesis. Data yang digunakan adalah data skor tes hasil belajar siswa dari kedua kelompok tersebut. Pengujian hipotesis yang digunakan dalam penelitian ini adalah uji-t. Sebelum dilakukan pengujian hipotesis untuk mendapatkan simpulan, maka prasyarat yang harus dipenuhi adalah melakukan uji asumsi klasik. Uji asumsi klasik yang dilakukan adalah uji asumsi normalitas dan homogenitas. Kemudian setelah data dikatakan berdistribusi normal dan data memiliki varian yang sama maka uji hipotesis dapat dilakukan. Uji hipotesis dalam penelitian ini dilakukan dengan menggunakan uji t. Uji normalitas bertujuan untuk menentukan apakah data yang diperoleh berdistribusi normal atau tidak. Uji normalitas dalam penelitian ini 
menggunakan teknik Kolmogorov-Smirnov. Dengan kriteria pengujian adalah data berdistribusi normal jika nilai sig > taraf signifikan 5\%. Dan uji homogenitas varians digunakan untuk mengetahui apakah varians kelompok eksperimen dan kelompok kontrol homogen. Dengan kriteria pengujian diterima hipotesis nol yang menyatakan bahwa tidak ada perbedaan varians antara kelompok eksperimen dan kelompok kontrol (data homogen) jika nilai signifikansi yang diperoleh lebih besar dari 0,05.

\section{HASIL DAN PEMBAHAHASAN Hasil}

Sebelum uji hipotesis dilakukan, terlebih dahulu dilakukan uji prasyarat terhadap sebaran data yang meliputi uji normalitas dan uji homogenitas varians. Dari hasil uji normalitas bahwa nilai pada sig kelas eksperimen sebesar 0,101 dan kelas kontrol sebesar 0,118 dengan tingkat signifikansi sebesar 0,05 , maka nilai sig pada kelas eksperimen dan kelas kontrol $>0,05$. Jadi dapat disimpulkan bahwa data berasal dari populasi berdistribusi normal. Serta dari hasil uji homogenitas nilai sig sebesar 0,373 > taraf signifikansi 0,05, maka hipotesis nol diterima. sehingga dapat disimpulkan bahwa tidak ada perbedaan varians antara kelompok eksperimen dan kelompok kontrol (data homogen). Berdasarkan kondisi tersebut maka dapat dilakukan pengujian hipotesis dengan menggunakan uji-t. Perbedaan Hasil belajar siswa pada mata pelajaran ekonomi antara kelompok siswa yang dibelajarkan dengan menggunakan model pembelajaran Auditory Intellectually Repetition (AIR) dengan kelompok siswa yang dibelajarkan tidak dengan menggunakan model pembelajaran Auditory Intellectually Repetition (AIR) pada siswa kelas X IPS di SMA Negeri 3 Singaraja tahun ajaran $2017 / 2018$ yang dianalisis dengan menggunakan uji-t dapat dilihat pada tabel 1 dibawah ini.

Tabel 1. Hasil Uji-t

Independent Samples Test

Levene's Test
for Equality of
Variances t-test for Equality of Means

\begin{tabular}{|c|c|c|c|c|c|c|c|c|c|c|}
\hline & & \multirow[b]{2}{*}{$\mathrm{F}$} & \multirow[b]{2}{*}{ Sig. } & \multirow[b]{2}{*}{$\mathrm{T}$} & \multirow[b]{2}{*}{ df } & \multirow{2}{*}{$\begin{array}{l}\text { Sig. (2- } \\
\text { tailed) }\end{array}$} & \multirow{2}{*}{$\begin{array}{c}\text { Mean } \\
\text { Difference }\end{array}$} & \multirow{2}{*}{$\begin{array}{l}\text { Std. Error } \\
\text { Differenc } \\
\mathrm{e}\end{array}$} & \multicolumn{2}{|c|}{$\begin{array}{l}\text { 95\% Confidence } \\
\text { Interval of the } \\
\text { Difference }\end{array}$} \\
\hline & & & & & & & & & Lower & Upper \\
\hline \multirow[t]{2}{*}{ Nilai } & $\begin{array}{l}\text { Equal variances } \\
\text { assumed }\end{array}$ & .804 & .373 & 7.425 & 65 & .000 & 17.67380 & 2.38021 & 12.92018 & 22.42741 \\
\hline & $\begin{array}{l}\text { Equal variances } \\
\text { not assumed }\end{array}$ & & & 7.406 & 62.415 & .000 & 17.67380 & 2.38649 & 12.90391 & 22.44368 \\
\hline
\end{tabular}

Berdasarkan tabel 1 dapat dilihat bahwa nilai sig sebesar $0,000<$ taraf signifikansi 0,05 , sehingga $\mathrm{HO}$ ditolak dan $\mathrm{Ha}$ diterima, maka dapat disimpulkan bahwa terdapat perbedaan hasil belajar siswa pada mata pelajaran ekonomi antara kelompok siswa yang belajar dengan menggunakan model pembelajaran Auditory Intellectually Repetition (AIR) dengan kelompok siswa yang belajar tidak dengan menggunakan model pembelajaran Auditory Intellectually Repetition (AIR) pada siswa kelas $X$ IPS di SMA Negeri 3 Singaraja tahun ajaran 2017/2018.

\section{Pembahasan}

Berdasarkan hasil penelitian terdapat perbedaan hasil belajar ekonomi antara kelompok siswa yang belajar dengan menggunakan model pembelajaran Auditory Intellectually Repetition (AIR) dengan kelompok siswa yang belajar tidak dengan model pembelajaran Auditory Intellectually Repetition (AIR). Hal ini terjadi 
karena dalam proses pembelajaran dengan menggunakan model pembelajaran Auditory Intellectually Repetition (AIR) siswa memanfaatkan indera yang dimilikinya secara maksimal mulai dari indera telinga yang digunakan untuk mendengar penyampaian dari guru dan temannya, berbicara, dan menanggapi, kemudian menggunakan kemampuan berpikirnya untuk memecahkan suatu permasalahan yang diberikan serta dilanjutkan dengan latihan untuk memantapkan apa yang telah dipelajarinya sehingga akan meningkatkan hasil belajar siswa.

Model pembelajaran AIR merupakan model pembelajaran yang menekankan tiga aspek, yaitu auditory, intellectually, dan repetition. Auditory bermakna bahwa belajar harus melalui mendengarkan, menyimak, berbicara, presentasi, argumentasi, mengemukakan pendapat, dan menanggapi. Intellectually bermakna belajar harus menggunakan kemampuan berpikir, harus dengan konsentrasi pikiran dan berlatih menggunakannya melalui bernalar, menyelidiki, mengidentifikasi, menemukan, mencipta, mengonstruksi, memecahkan masalah dan menerapkan. Repetition artinya pengulangan, dengan tujuan memperdalam dan memperluas pemahaman siswa yang perlu dilatih melalui pengerjaaan soal, pemberian tugas, dan kuis. Pengulangan dalam kegiatan pembelajaran dimaksudkan agar pemahaman siswa lebih mendalam (Suherman dalam Shoimin, 2014). Dengan mengintegrasikan ketiga aspek tersebut, akan membuat siswa lebih aktif dalam proses pembelajaran untuk memahami materi dan konsep yang belajar, sehingga siswa tidak hanya sekadar menghafal yang nantinya membuat siswa menjadi cepat lupa terhadap konsep yang telah dipelajari.

Pelaksanaan pembelajaran dengan model pembelajaran Auditory Intellectually Repetition (AIR) ini diawali dengan memberikan apersepsi kepada siswa serta mengingat kembali materi sebelumnya. Kemudian dilanjutkan dengan menyampaikan materi secara garis besar. Tahap ini merupakan tahap auditory. Setelah itu, dilanjutkan dengan membagi siswa ke dalam beberapa kelompok kecil.
Dalam pembentukan kelompok ini, siswa diarahkan untuk membentuk kelompok dengan anggota setiap kelompok 5-6 orang. Setelah kelompok tersebut terbentuk, setiap kelompok diberikan LKS yang berisi permasalahan. Selanjutnya siswa mendiskusikan permasalahan yang terdapat dalam LKS tersebut. Pada tahap ini disebut tahap intellectually. Siswa diberikan kesempatan untuk menemukan penyelesaian permasalahan yang diberikan dengan menggunakan kemampuan yang telah dimiliki masing-masing individu dalam setiap kelompok. Setelah siswa selesai berdiskusi, dilanjutkan dengan presentasi hasil diskusinya. Kelompok yang tidak presentasi memberikan tanggapan atau sanggahan jika mempunyai pendapat yang berbeda. Pada tahap akhir, siswa diberikan kuis tentang materi yang telah dibahas pada pertemuan tersebut untuk meningkatkan pemahaman yang dimiliki oleh siswa berkaitan dengan materi yang telah dipelajari. Namun jika waktunya tidak cukup akan diganti dengan pemberian tugas. Ini mengakibatkan siswa yang belajar dengan model pembelajaran Auditory Intellectually Repetition (AIR) memiliki pemahaman yang lebih mendalam daripada siswa yang belajar tidak dengan model pembelajaran Auditory Intellectually Repetition (AIR). Selain memberikan kesempatan untuk mengembangkan kemampuan komunikasi dengan menggunakan model pembelajaran Auditory Intellectually Repetition (AIR), siswa juga diberikan kesempatan untuk mengembangkan kemampuan intelektualnya dengan jalan pemecahan masalah, menganalisis, dan menghubungkan informasi yang telah diperoleh sebelumnya dengan permasalahan yang sedang dihadapi.

Hasil penelitian yang menyatakan terdapat perbedaan hasil belajar ekonomi antara kelompok siswa yang belajar dengan menggunakan model pembelajaran Auditory Intellectually Repetition (AIR) dengan kelompok siswa yang belajar tidak menggunakan model pembelajaran Auditory Intellectually Repetition (AIR) juga sejalan dengan penelitian yang dilakukan oleh Hasna (2015) yang menyimpulkan bahwa aktivitas belajar 
siswa pada mata pelajaran ekonomi yang belajar dengan model pembelajaran Auditory Intellectually Repetition (AIR) lebih tinggi dari pada siswa yang belajar tidak dengan model pembelajaran Auditory Intellectually Repetition (AIR). Dari hasil penelitian yang telah dilakukan ada beberapa kendala yang ditemukan yaitu siswa sulit dalam pembentukan kelompok dengan kemampuan heterogen karena siswa sudah mempunyai kelompok belajar tetap dan dalam menerapkan model pembelajaran Auditory Intellectually Repetition (AIR) memerlukan waktu yang cukup lama.

Dari uraian di atas, menunjukkan bahwa penerapan model pembelajaran Auditory Intellectually Repetition (AIR) dalam pembelajaran ekonomi memberikan pengaruh yang positif terhadap hasil belajar ekonomi siswa. Oleh karena itu, terdapat perbedaan hasil belajar ekonomi antara siswa yang belajar dengan menggunakan model pembelajaran Auditory Intellectually Repetition (AIR) dengan siswa yang belajar tidak dengan model pembelajaran Auditory Intellectually Repetition (AIR).

\section{SIMPULAN DAN SARAN}

Berdasarkan hasil penelitian dan pembahasan, maka dapat disimpulkan bahwa terdapat perbedaan hasil belajar ekonomi antara kelompok siswa yang belajar dengan menggunakan model pembelajaran Auditory Intellectually Repetition (AIR) dengan kelompok siswa yang belajar dengan menggunakan model pembelajaran konvensional. Hasil pengujian menunjukkan bahwa nilai sig sebesar 0,000 < taraf signifikansi 0,05.

$$
\text { Adapun saran yang dapat }
$$

disampaikan berdasarkan hasil penelitian yang telah dilakukan yaitu, yang pertama bagi sekolah, penggunaan model Auditory Intellectually Repetition (AIR) dapat menjadi salah satu alternatif pembelajaran dalam proses belajar mengajar disemua mata peljaran, kedua bagi guru, diharapkan guru bisa mengembangkan proses pembelajaran dengan menggunakan model pembelajaran Auditory Intellectually Repetition (AIR) sebagai salah satu alternatif model pembelajaran khususnya pada mata pelajaran ekonomi, dan ketiga bagi peneliti selanjutnya, penelitian ini hanya bertujuan untuk mengetahui pengaruh model pembelajaran Auditory Intellectually Repetition (AIR) terhadap hasil belajar ekonomi siswa pada ranah kognitif. Peneliti lain yang tertarik disarankan untuk meneliti variabel terikat yang lain misalnya aktivitas siswa, motivasi belajar serta kemampuan berpikir kritis.

\section{DAFTAR PUSTAKA}

Candiasa, I Made. 2010. Undiksh Press, Statistik Univariat dan Bivariat Disertai Aplikasi SPSS. Singaraja: Universitas Pendidikan Ganesha.

Depdiknas. 2003. Media Pembelajaran. Jakarta: Depdiknas.

Handayani, I M. 2013. Keefektifan Model Auditory Intellectually Repetition (AIR) berbantuan LKPD terhadap Kemampuan Penalaran Matematis Peserta Didik SMP. Skripsi Jurusan Matematika Universitas Negeri .

Hasna, Fitra Dara. 2016. "Pengaruh Penerapan Model Pembelajaran Auditory Intellectually Repetition (AIR) Terhadap Aktivitas Belajar Siswa Pada Mata Pelajaran Ekonomi Di Sekolah Menengah Atas Negeri 1 Kampar Timur". Skrips (tidak diterbitkan), Universitas Islam Negeri Sultan Syarif Kasim Riau.

Huda, Miftahul. 2013. Model-Model Pengajaran dan Pembelajaran. Yogyakarta : Pustaka Pelajar.

Irianto, Agus. 2004. Statistik :Konsep Dasar, Aplikasi, dan Pengembangannya Edisi Pertama. Jakarta : Kencana Prenada Media Group.

Komalasari, Kokom. 2011. Pembelajaran Kontekstual Konsep dan Aplikasi. Bandung: PT Refika Aditama.

Neti \& Leni P. (2010). Perencanaan Pembelajaran Ekonomi. Bandung: Laboratorium Pendidikan Ekonomi dan Koperasi. Universitas Pendidikan Indonesia. 
Oemar, Hamalik. 2005. Perencanaan Pengajaran Berdasarkan Pendekatan Sistem, Jakarta: PT. Bumi Aksara.

Purwanto. 2011. Evaluasi Hasil Belajar. Yogyakarta: Pustaka Belajar.

Shoimin, Aris. 2014. 68 Model Pembelajara Inovatif dalam Kurikuum 2013. Yogyakarta : Ar-Ruzz Media.

Slameto. 2010. Belajar dan Faktor-Faktor yang Mempengaruhinya. Jakarta: PT Rineka Cipta.

Sudijono, Anas. 2009. Pengantar Evaluasi Pendidikan. Jakarta : Rajawali Pers.

Sugiyono. 2010. Statistik untuk Penelitian. Bandung : Alfabeta.

Sukardi. 2008. Evaluasi Pendidikan: Prinsip dan Operasionalnya. Jakarta: Bumi Aksara.

Suryabrata S. 2006. Psikologi Pendidikan. Jakarta: PT Raya Erafindo Persada

Trianto. 2007. Model-Model pembelajaran Inovatif Berorientasi Konstruktivistik. Cetakan pertama. Jakarta.

Undang-Undang No. 20 Tahun 2003 tentang Sistem Pendidikan Nasional.

Uno.B, Hamzah. 2008. Teori Motivasi dan Pengukurannya, edisi pertama. Cetakan ketiga. Jakarta: Bumi Aksara. 